\title{
Assessment of Serpentine Group Minerals in Soils: A Case Study from the Village of San Severino Lucano (Basilicata, Southern Italy)
}

\author{
Rosalda Punturo ${ }^{1}$, Claudia Ricchiuti ${ }^{1}$ and Andrea Bloise ${ }^{2, *(\mathbb{D}}$ \\ 1 Department of Biological, Geological and Environmental Sciences, University of Catania, Corso Italia, 55, \\ 95129 Catania, CT, Italy; punturo@unict.it (R.P.); claudia.ricchiuti@unict.it (C.R.) \\ 2 Department of Biology, Ecology and Earth Sciences, University of Calabria, Via Pietro Bucci, \\ I-87036 Rende, Italy \\ * Correspondence: andrea.bloise@unical.it; Tel.: +39-0984-493588
}

Received: 30 January 2019; Accepted: 19 February 2019; Published: 25 February 2019 updates

\begin{abstract}
Naturally occurring asbestos (NOA) is a generic term used to refer to both regulated and un-regulated fibrous minerals when encountered in natural geological deposits. These minerals represent a cause of health hazard, since they have been assessed as potential environmental pollutants that may occur both in rocks and derived soils. In the present work, we focused on the village of San Severino Lucano, located in the Basilicata region (southern Apennines); due to its geographic isolation from other main sources of asbestos, it represents an excellent example of hazardous and not occupational exposure of population. From the village and its surroundings, we collected eight serpentinite-derived soil samples and carried out Differential Scanning Calorimetry (DSC), Derivative Thermogravimetric (DTG) and Transmission Electron Microscopy with Energy Dispersive Spectrometry (TEM-EDS), in order to perform a detailed characterization of serpentine varieties and other fibrous minerals. Investigation pointed out that chrysotile and asbestos tremolite occur in all of the samples. As for the fibrous but non-asbestos classified minerals, polygonal serpentine and fibrous antigorite were detected in a few samples. Results showed that the cultivation of soils developed upon serpentinite bedrocks were rich in harmful minerals, which if dispersed in the air can be a source of environmental pollution.
\end{abstract}

Keywords: serpentine varieties; naturally occurring asbestos; health hazard; serpentinite soil

\section{Introduction}

As it is known, the term "asbestos" represents a group of six fibrous silicate minerals: chrysotile (serpentine group) and amphibole group as: tremolite, actinolite, anthophyllite, amosite and crocidolite $[1,2]$. In the past, asbestos was plenty been exploited and marketed for the use in industrial and commercial products, mainly as building material [3]. All types of asbestos cause lung cancer, mesothelioma, cancer of the larynx and ovary, and asbestosis (fibrosis of the lungs) [2]. It has been assessed that exposure to asbestos occurs through inhalation of airborne fibers in various contexts such as the working environment, ambient air in the vicinity of point sources such as factories handling asbestos, or indoor air in housing and buildings containing friable asbestos materials [4]. Nevertheless, it is worth noting that natural occurrences of asbestos represent a cause of health hazard, which is sometimes overlooked and difficult to properly monitor. Indeed, naturally occurring asbestos (NOA) is a generic term used to refer to both regulated and non-regulated fibrous minerals when encountered in natural geological deposits [5]. Now-a-days, only the six varieties above listed are regulated as potential environmental pollutants by law (in Europe and in several countries 
worldwide), even though other asbestiform minerals such as balangeorite, erionite, fibrous antigorite and fluoro-edenite [6-9] are non-asbestos classified and, therefore, not regulated by law but could be potentially dangerous if inhaled. On the basis of the effects of asbestos on biological systems, several authors ascribe the asbestos-fibers toxicity to the synergetic effect of fiber size, bio-persistence and chemical composition [10-13]; this latter is related to the high capability of asbestos minerals to host a large number of toxic elements; for this reason, due to interactions between lung fluids and inhaled atmospheric dust $[14,15]$, some researchers claimed that asbestos fibers may play a passive role in producing diseases as carriers of heavy metals that may be then released into the environment [16]. In general, many factors such as natural weathering processes (e.g., erosion) and human activities (e.g., excavation, road construction, agricultural activities) contribute to NOA release in the environment $[13,17]$, enhancing hazard of people who live near to NOA deposits around the world [18-25].

In the present study we focused on the Basilicata region (Italy) [26], where an increased number of lung disease cases were related to the environmental exposure to asbestos [27-29]. The village and its surroundings represent an excellent example of hazardous and not occupational exposure of population to asbestos, because of the geographic isolation and its distance from other main sources of asbestos for instance.

Recently, a work by Punturo et al. [30] dealt with the characterization by X-Ray Fluorescence (XRF), X-Ray Powder Diffraction (XRPD) and Scanning and Electron Microscopy (SEM) of the soils of San Severino Lucano, reporting their potential for hazardous exposure of population, because of their heavy metal content. However, the discrimination among the serpentine group minerals (i.e., lizardite, antigorite chrysotile, polygonal serpentine) was not achievable by using only $\mathrm{X}$-ray powder diffraction, because the diffraction peaks overlap each other. Moreover, scanning electron microscopy (SEM) alone could not determine the diameter of single fibrils. Since these last techniques were not able to identify the different serpentine varieties, in this work a more targeted characterization of soil samples was performed by Differential Scanning Calorimetry (DSC), Derivative thermogravimetric (DTG) and Transmission Electron Microscopy with Energy Dispersive Spectrometry (TEM-EDS). We collected eight serpentinite soil samples and cross-checked the data obtained from DSC, DTG and TEM-EDS, in order to perform a detailed characterization and discrimination among the serpentine varieties and other fibrous minerals, as well as to relate NOA release in the environment due to agricultural activity. Investigation highlighted that chrysotile and asbestos tremolite are the asbestos minerals occurring in all of the analyzed soils, appearing both as single fibrils and bundles. As for the fibrous but non-asbestos classified minerals, polygonal serpentine and fibrous antigorite were detected in a few samples. Because of the fibrous structure, longitudinal splitting of these minerals is very common, creating thus fibers having the same length as the original one but with smaller diameter. Furthermore, the cultivation of soils developed on serpentinite bedrocks could enhance this process and provoke the release of smaller fibrils into the environment, increasing thus the exposure of population to asbestos risk. Results may provide a useful tool for planning prevention measures during agricultural activities, in order to diminish negative effects of NOA on health.

\section{Geological Setting}

This study area encompasses approximately $20 \mathrm{~km}^{2}$ in the Pollino National Park [16], which is located at the borders between the Basilicata and Calabria regions (southern Italy; Figure 1). 


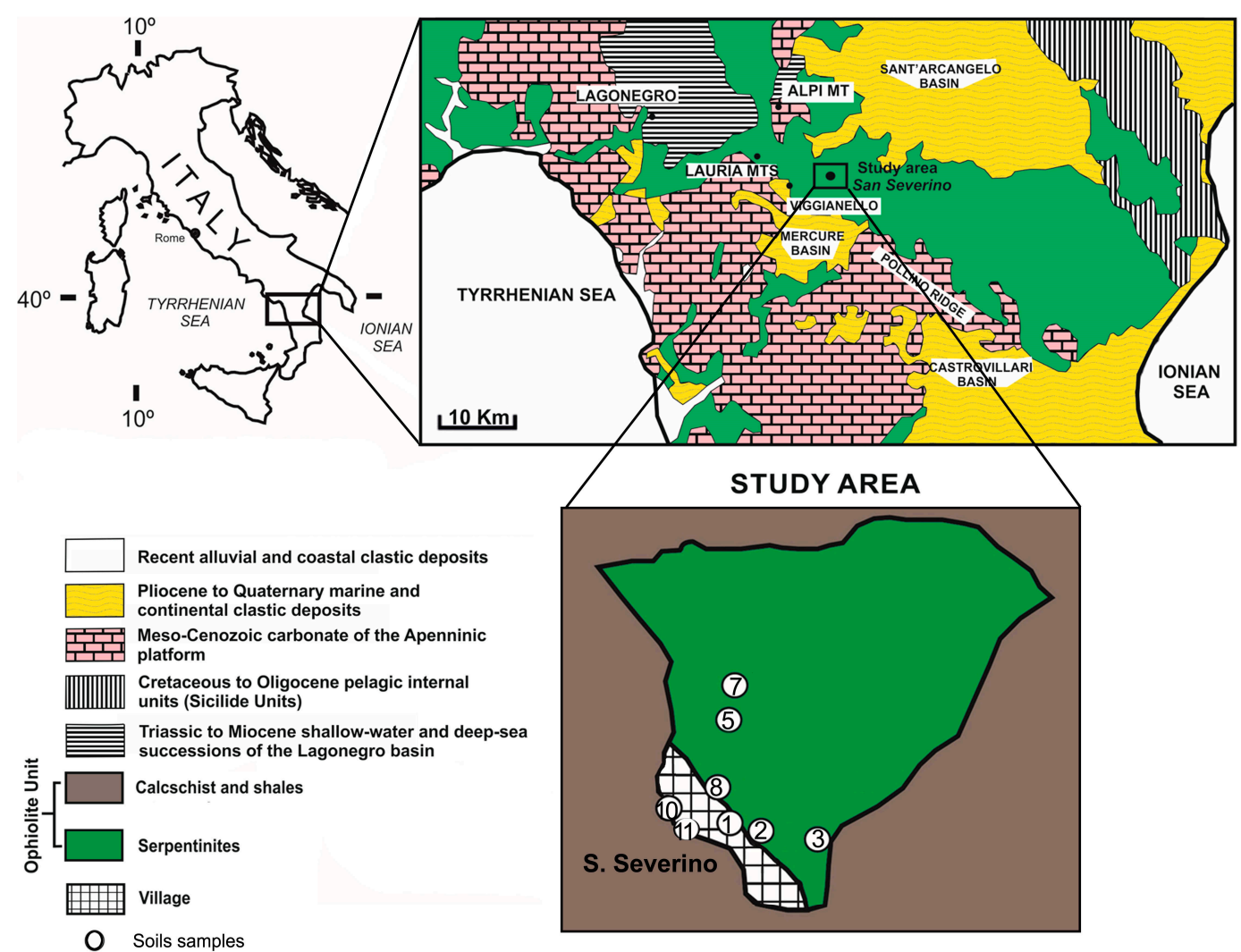

Figure 1. Geological map of the Calabria-Lucania border (modified after [30]) and study area location with sampling sites.

The area is characterized by the terrains of the Liguride Complex, which consists of three main tectonic units of Upper Jurassic to Upper Oligocene age [31]: (1) the Calabro-Lucano Flysch [32], a unit that did not underwent any metamorphism and partly corresponds to the North-Calabrian Unit; (2) the metamorphic terranes of the Frido Unit [33,34]; (3) syn-orogenic turbiditic sequences, i.e., the Saraceno Formation, the Albidona Formation, and a sequence composed of alternating shales, mudstones and sandstones, the latter corresponding to the Perosa Unit as defined by Vezzani [35]. The ophiolites of the Southern Apennine Liguride Units occur in the Frido Unit and in the North-Calabrian Unit. In particular, ophiolitic rocks of the Frido Unit consist of lenticular metabasites interbedded with cataclastic and highly fractured serpentinite rocks [36]. Metabasite rocks are foliated and fine-grained, with rare remnants of porphyritic texture. They are often intercalated with serpentinites, slates and metacarbonate rocks [37], forming sequences with a maximum thickness of several dozen metres. Serpentinite rocks, which are green-bluish in colour, represent mantle peridotites [38]. Locally, serpentinites are very brittle, as indicated by the large number of fractures that are usually filled by amphibole asbestos. As it may be observed on Figure 1, serpentinite lithotypes constitute the bedrock of the village of San Severino Lucano and its surroundings. The detailed field survey carried out along the transect of sampling sites located at San Severino village and its surroundings (Figure 1), highlighted that the area is characterized by sparse vegetation and by soils developed on serpentinite bedrocks (Figure 2a-e). 


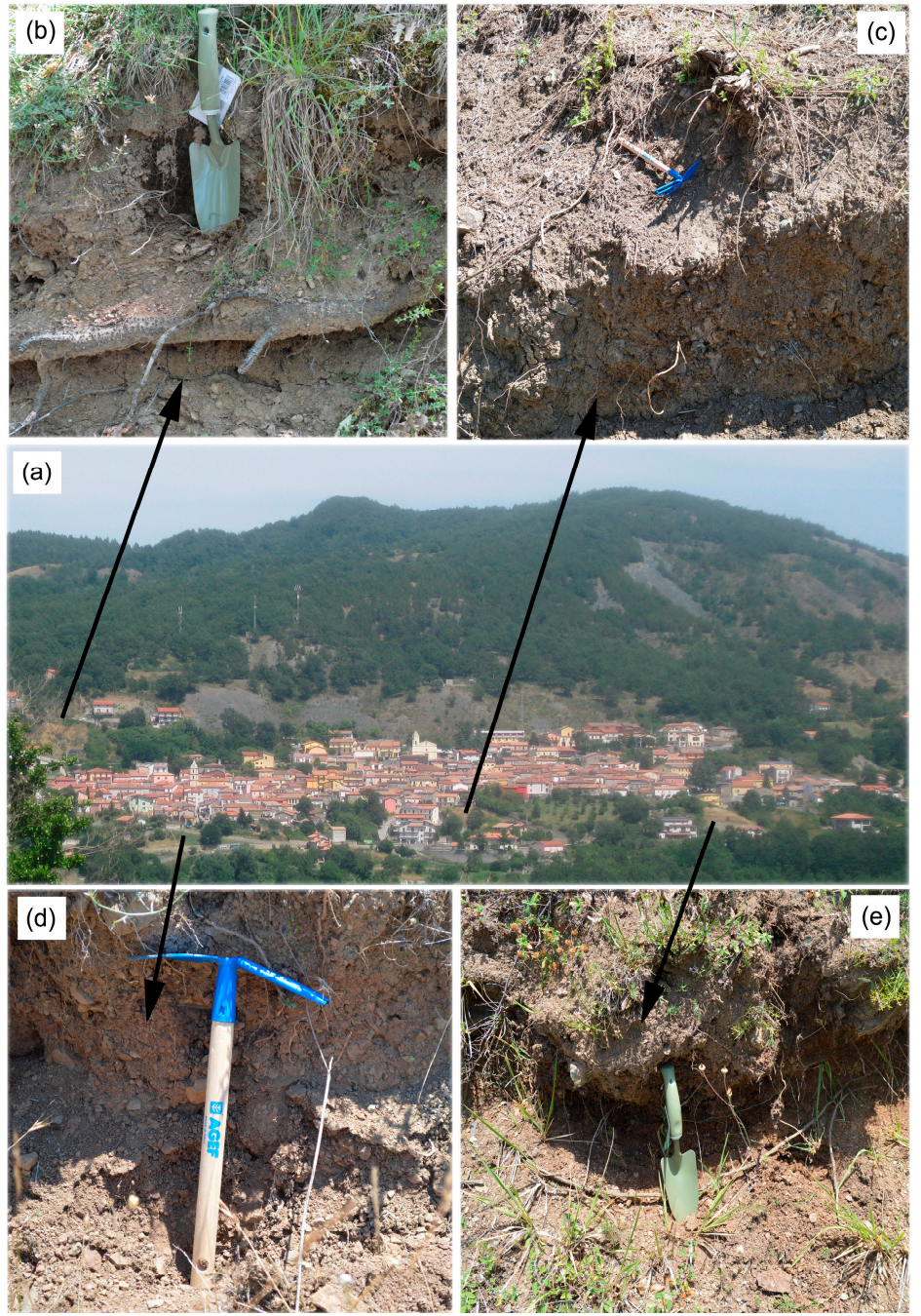

Figure 2. (a) Distant view of the San Severino Village (modified after [26]); (b) soil outcrop that contain NOA (Spol8); (c) soil outcrop (Spol1); (d) soil outcrop (Spol10); (e) soil outcrop (Spol2).

\section{Materials and Methods}

Eight serpentinite derivative soil samples (Spol1,2,3,5,7,8,10,11) were collected mainly within to urban center and analyzed by using TEM-EDS and thermal analyzes (DSC, DTG) at the University of Calabria (DiBEST laboratory), in order to investigate their mineralogical features and to assess the occurrence of asbestiform minerals, which are considered to be potentially hazardous for human health [13]. It is worth mentioning that combination of both analytical methodologies, i.e., thermal analysis and TEM-EDS, permitted successful identification of distinct serpentine minerals (antigorite, lizardite, chrysotile, and polygonal serpentine) and the characterization of amphibole asbestos [13]. Moreover, the length of fibrous antigorite and polygonal serpentine fibers has been measured using the TEM micrographs, adding further details to the previous observations carried out with SEM [30]. The soil samples were pre-treated with $\mathrm{H}_{2} \mathrm{O}_{2}$ and pre-heated for $24 \mathrm{~h}$ at $530{ }^{\circ} \mathrm{C}$, in order to remove the organic compounds and so that they could be subsequently ground. Size and chemical composition of single fibers were determined using a Jeol JEM 1400 Plus (120 kV) Transmission Electron Microscope equipped with Jeol large-area silicon drift detector SDD-EDS (Jeol, Tokyo, Japan) for microanalyses. For TEM investigation, each sample was put into isopropyl alcohol and then sonicated. Three drops of the obtained suspension were deposited on a Formvar carbon-coated copper grid.

Thermogravimetry (TG) and differential scanning calorimetry (DSC) were performed in an alumina crucible under a constant aseptic air flow of $30 \mathrm{~mL} \cdot \mathrm{min}^{-1}$ with a Netzsch STA $449 \mathrm{C}$ 
Jupiter (Netzsch-Gerätebau GmbH, Selb, Germany) in the $25-1000{ }^{\circ} \mathrm{C}$ temperature range with a heating rate of $10^{\circ} \mathrm{C} \cdot \mathrm{min}^{-1}$ and $20 \mathrm{mg}$ of sample powder. Instrumental precision was checked by 5 repeated collections on a kaolinite reference sample revealing good reproducibility (instrumental theoretical T precision of $\pm 1.2{ }^{\circ} \mathrm{C}$ ). Netzsch Proteus thermal analysis software (Netzsch-Gerätebau $\mathrm{GmbH}$, Selb, Germany) was used to identify exo- and endothermic peaks, weight loss and derivative thermogravimetric (DTG).

\section{Results}

\subsection{TEM Characterization}

TEM has been mainly useful to determine the occurrence of serpentine varieties and their morphological features in the soil samples; indeed, distinct fibrous serpentine varieties have been found such as chrysotile, fibrous antigorite, polygonal serpentine and tremolite (Figure 3). They exhibit various shape and size. Chrysotile appears as thin individual fibers (known as fibrils) and often forms relatively larger longitudinally aligned fibers (Figure 3a,b).
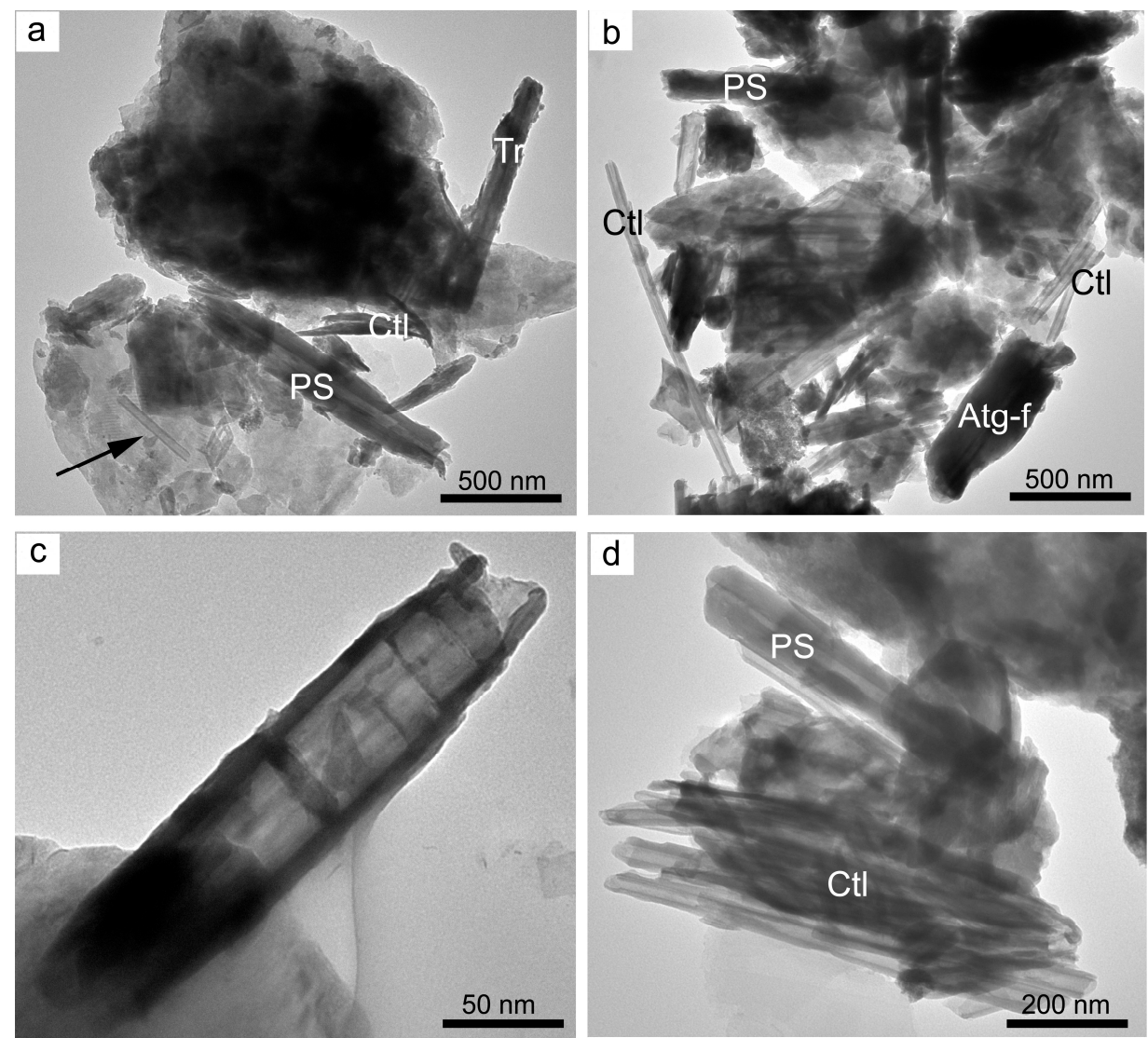

Figure 3. Representative TEM images of fibrous mineral detected in the soil samples: (a) bundles of chrysotile fibers; chrysotile fiber characterized by the empty central cavity and thin outer walls indicated by black arrow; polygonal serpentine and fibrous tremolite (sample Spol1); (b) chrysotile fibers, polygonal serpentine and fibrous antigorite (Spol3); (c) chrysotile fiber partially unrolled from the inside like cylinder-in-cylinder morphology (Spol10); (d) polygonal serpentine and bundles of chrysotile fibers (Spol11). $\mathrm{Ctl}=$ chrysotile; $\mathrm{Tr}=$ tremolite; Atg- $\mathrm{f}=$ fibrous antigorite; $\mathrm{PS}=$ polygonal serpentine (mineral symbols after Whitney and Evans [39]).

From Figures 3 and 4 it is evident the classical cylindrical shape of chrysotile fibers; this is the most common morphology in all of the samples, consisting of an empty central cavity (core) along throughout their length. The length varies from 300 to $1500 \mathrm{~nm}$ and the diameter of the core is about 
$20 \mathrm{~nm}$ and $40 \mathrm{~nm}$ inner and outer, respectively. In some samples the outer walls of chrysotile are very thin and the central tube (core) is wide, measuring about $40 \mathrm{~nm}$ (Figure $3 \mathrm{a}, \mathrm{b}$ ). This proves that the chrysotile underwent an unrolling process from the inside during the process of alteration from rock to soil, likely caused by the passage of water through the core (Figure 3c). Chrysotile with cylinder-en-cylinder and proto-cylinder morphologies have also been found with TEM investigation; these do not show the well-defined wrapping of layers and cylindrical shape that the chrysotile fibers exhibited (Figure 4).
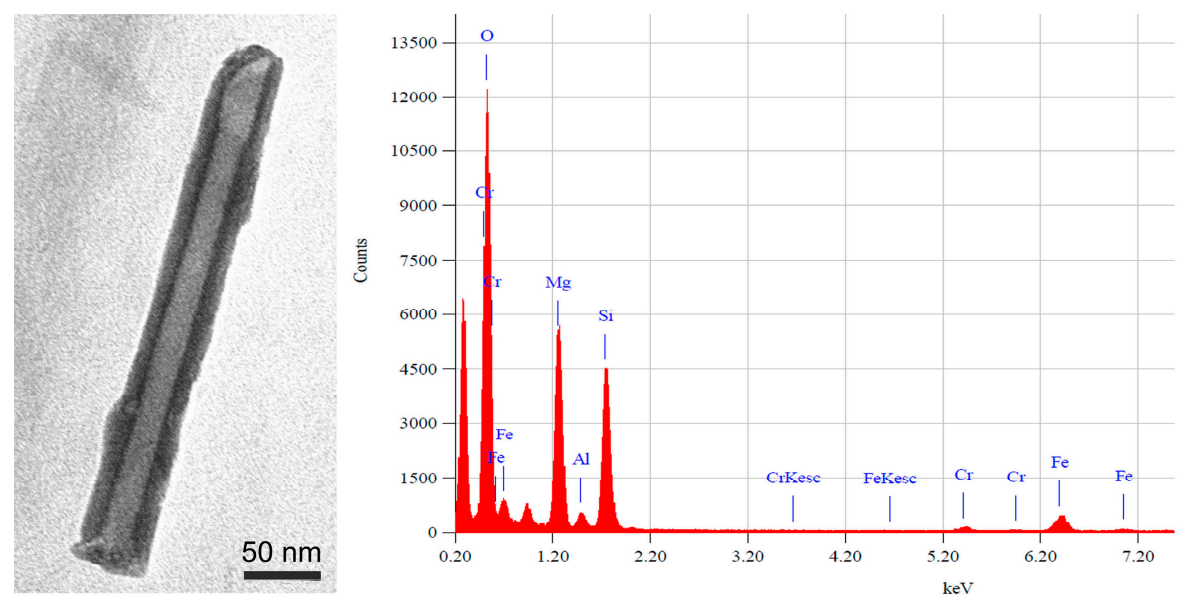

Figure 4. Single cylinder chrysotile with the relative point analysis (Spol1).

Fibrous polygonal serpentine is another structural variety that has been found in most of the studied samples (Table 1); it occurs in lower amount and has very often a diameter larger than $100 \mathrm{~nm}$ and wider than the chrysotile individuals (Figure 3a,b,d). Antigorite fibers are the shortest, with length and width of 1000 and $300 \mathrm{~nm}$ respectively. However, fibrous antigorite has been identified only in two samples (Figure $3 \mathbf{b}$; Table 1), with platy antigorite the most abundant morphology observed in all of the studied specimens. Lizardite with platy morphology was also detected in a few samples (Table 1). Tremolite fibers have also been observed. TEM micrographs reported on Figures 3a and 5, show the typical morphology of tremolite fibers, which exhibit prismatic rod-shaped morphology lacking of any flexibility. In these fibers, the average length ranges from $2.5 \mu \mathrm{m}$ to $3 \mu \mathrm{m}$ and the diameter is about $0.2 \mu \mathrm{m}$.
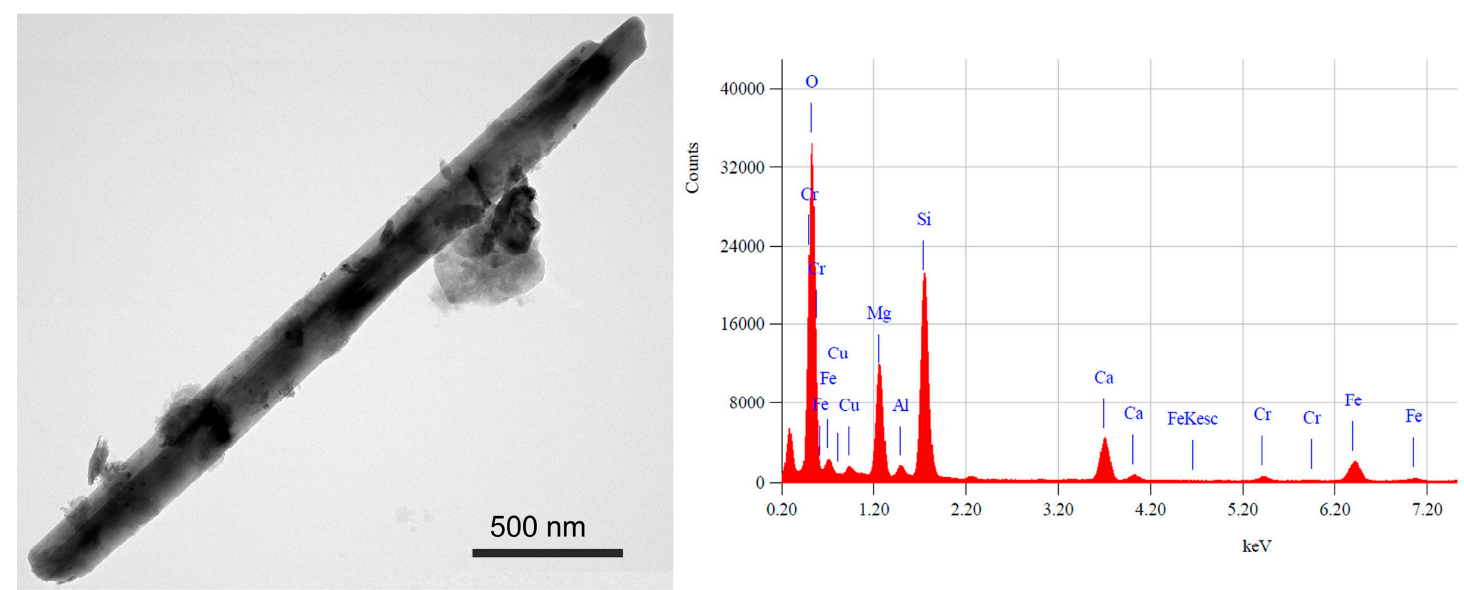

Figure 5. Single tremolite fiber with the relative point analysis (Spol1). 
Table 1. Studied localities, reference coordinates and, for each collected soil sample, mineralogical assemblage detected by X-ray powder diffraction (XRPD) and by scanning electron microscopy combined with energy dispersive spectrometry (SEM-EDS) * after [30]. Serpentine minerals varieties and amphiboles detected by DSC, DTG and TEM-EDS. Chlorite (Chl), chrysotile (Ctl), polygonal serpentine (PS), lizardite (Liz), fibrous antigorite (f-Ant), antigorite (Atg) and tremolite (Tr) (mineral symbols after Whitney and Evans [39]). Amphiboles present in the samples were classified according to the amphibole diagram classification [40].

\begin{tabular}{clccc}
\hline Sample & \multicolumn{1}{c}{ Site Description } & $\begin{array}{c}\text { Longitude } \\
\text { (East) }\end{array}$ & $\begin{array}{c}\text { Latitude } \\
\text { (North) }\end{array}$ & Phases Detected \\
\hline Spol1 & At the entrance of the Village & 597,417 & $4,429,775$ & Ctl, PS, Ant, Tr (Di, Qtz, Mnt-Chl) * \\
Spol2 & At the entrance of the Village & 597,405 & $4,430,523$ & Ctl, f-Ant (Di, Qtz, Mnt-Chl, Tr) * \\
Spol3 & Road cut outside the Village & 597,808 & $4,430,474$ & Ctl, PS, Liz, f-Ant (Di, Qtz, Mnt-Chl, Tr) * \\
Spol5 & Road cut outside the Village & 597,270 & $4,431,103$ & Ctl, Liz, Ant (Di, Qtz, Mnt-Chl, Tr, Chm, Ms) * \\
Spol7 & Road cut outside the Village & 597,323 & $4,431,363$ & Ctl, Tr, (Di, Qtz, Mnt-Chl, Chm) * \\
Spol8 & Road cut within the Village & 597,223 & $4,430,711$ & Ctl, PS, Ant (Di, Qtz, Mnt-Chl, Tr, Chm)* \\
Spol10 & Road cut within the Village & 596,890 & $4,430,715$ & Ctl, PS, Ant (Di, Qtz, Mnt-Chl, Tr, Chm, Mo) * \\
Spol11 & Road cut within the Village & 596,890 & $4,430,715$ & Ctl, PS (Di, Qtz, Mnt, Tr, Chm) * \\
\hline
\end{tabular}

\subsection{Thermal Analysis Characterization}

Thermal analysis of all representative soil samples enabled us to recognize the constituent mineralogical phases, and in particular the serpentine varieties (i.e., antigorite, lizardite, chrysotile, polygonal serpentine) (Table 1). In Figure 6a, the DSC patterns describe the thermal behavior of the investigated samples. In the temperature range between 500 and $850{ }^{\circ} \mathrm{C}$, chrysotile lost its chemical-bonded water (strong endothermic peak on average temperature at $630{ }^{\circ} \mathrm{C}$, Figure $6 \mathrm{~b}$ ) causing the complete breakdown of the mineral structure. At higher temperature value, the crystallization of forsterite [41] generates a sharp exothermic peak recorded at about $830{ }^{\circ} \mathrm{C}$ (Figure 6a; Table 2). After thermal analysis, the chrysotile structure has completely changed at a molecular scale because of a phenomenon called pseudomorphosis, which leads to the complete transformation of asbestos minerals into non-hazardous silicates such as forsterite $[42,43]$.
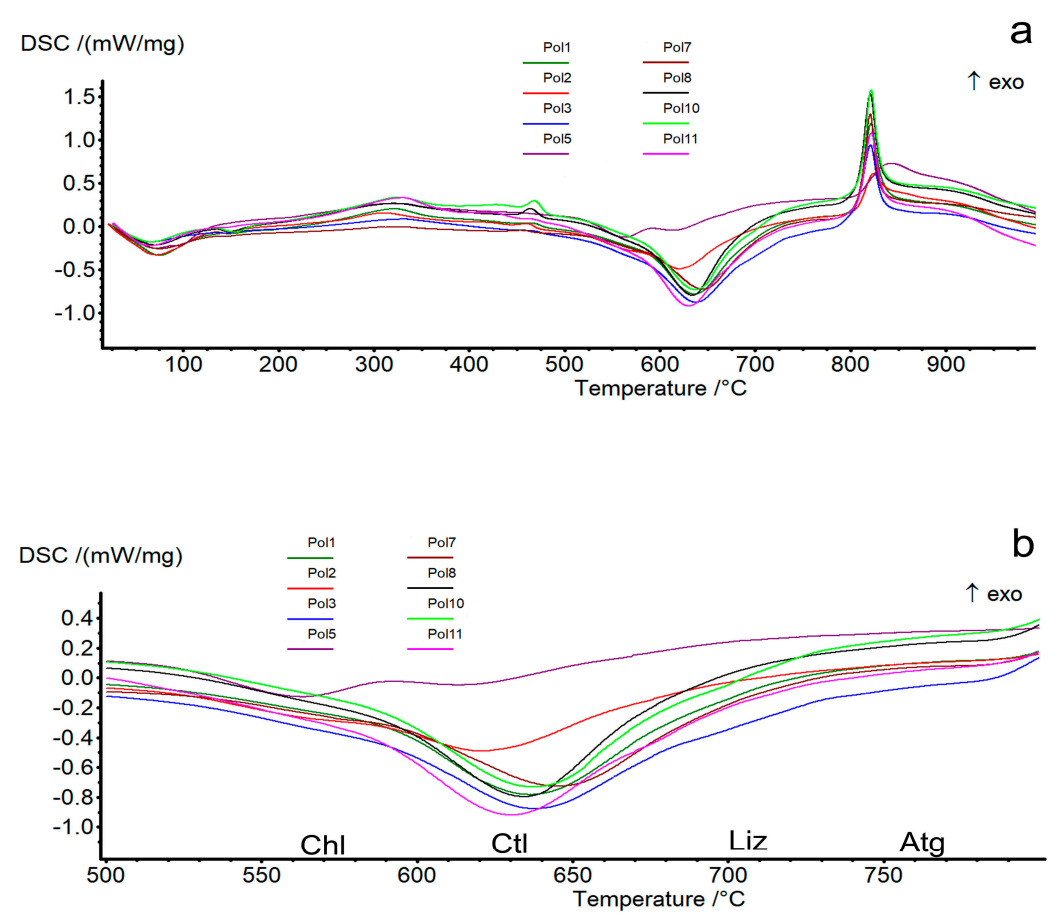

Figure 6. (a) Comparison among differential scanning calorimetry (DSC) curves of the soils located within or near the village of San Severino Lucano Village (Basilicata, Southern Italy); (b) zoom of (a) in the temperature range of $500-800{ }^{\circ} \mathrm{C}$. 
Table 2. Peak temperatures in DSC and DTG curves. $\mathrm{W}=$ weak, $\mathrm{vw}=$ very weak, $\mathrm{s}=$ strong, $\mathrm{ss}=$ very strong, $\mathrm{sh}=$ shoulder, en $=$ endothermic, $\mathrm{ex}=$ exothermic.

\begin{tabular}{|c|c|c|c|c|c|c|c|c|}
\hline Samples & Spol1 & Spol2 & Spol3 & Spol5 & Spol7 & Spol8 & Spol10 & Spol11 \\
\hline \multicolumn{9}{|c|}{ DSC } \\
\hline Chl & & & & 563 en $(w)$ & & & & \\
\hline $\mathrm{Ctl}$ & 636 en $(\mathrm{s})$ & 621 en(s) & 638 en (s) & 612 en (w) & 645 en $(w)$ & 634 en(s) & 637 en(s) & 630 en(s) \\
\hline Fo & 822 ex(ss) & 824 ex(ss) & 821 ex(ss) & 844 ex(s) & 821 ex(ss) & 821 ex(ss) & 822 ex(ss) & 822 ex(ss) \\
\hline \multicolumn{9}{|c|}{ DTG } \\
\hline Chl & & 564 en $(\mathrm{vw})$ & & 563 en $(w)$ & & & & \\
\hline $\mathrm{Ctl}$ & 637 en(ss) & 619 en $(\mathrm{s})$ & 638 en(s) & 614 en $(w)$ & 647 en(ss) & 634 en(s) & 639 en(ss) & 631 en(ss) \\
\hline PS & 679 en(vw) & & 686 en(vw) & & & 677 en(vw) & 688 en(vw) & 679 en (vw) \\
\hline Liz & & & 736 en (sh) & 744 en(sh) & & & & \\
\hline Ant & 774 en(sh) & 784 en(vw) & 784 en(sh) & 790 en (w) & & 778 en(sh) & 770 en(sh) & \\
\hline
\end{tabular}

DTG curves appear to be similar for most of the samples and show the main endothermic peaks related to the mineralogical phases decomposition between 500 and $830{ }^{\circ} \mathrm{C}$ (Figure 7). A weak endothermic peak at 563 and $564{ }^{\circ} \mathrm{C}$ for Spol2 and Spol5 respectively, is linked to the presence of a small amount of chlorite. For all samples, the very strong endothermic peak in a temperature range of 614-639 ${ }^{\circ} \mathrm{C}$, clearly showed the presence of chrysotile in high amount (Table 2).

Polygonal serpentine occurs in most of the samples showing a weak endothermic peak in a range of $677-688{ }^{\circ} \mathrm{C}$, whereas only two samples, Spol3 and Spol5, are characterized by an endothermic shoulder at 736 and $744^{\circ} \mathrm{C}$ related to the presence of lizardite (Table 2). Finally, the occurrence of antigorite is confirmed by the endothermic peak in a $\mathrm{T}$ range of $770-790{ }^{\circ} \mathrm{C}$ (Table 2).

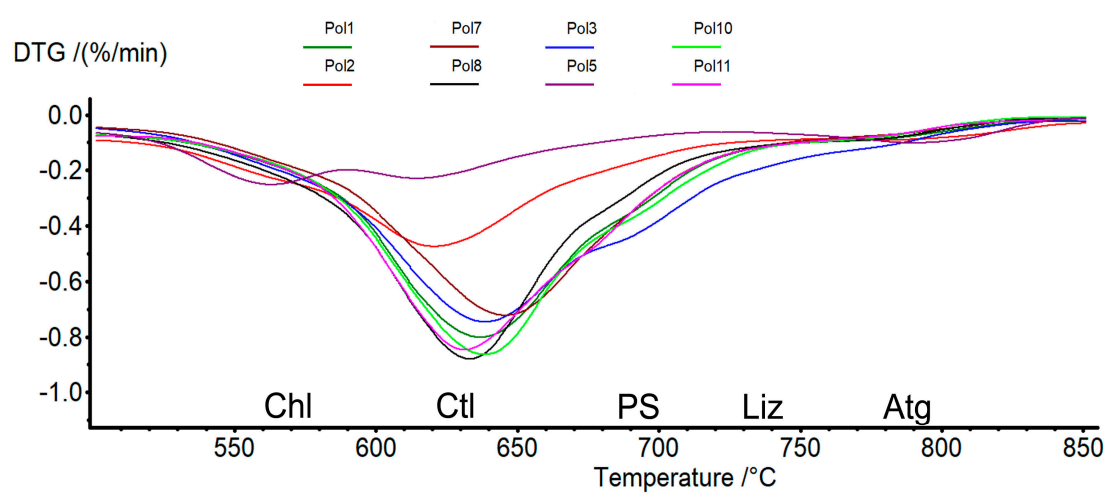

Figure 7. Comparison among DTG curves in the temperature range of $500-850{ }^{\circ} \mathrm{C}$ : endothermic peaks related to chlorite (Chl), chrysotile (Ctl), polygonal serpentine (PS), lizardite (Liz) and antigorite (Atg) decomposition.

The TG data reported on Table 3, show the values of $1-4 \%$ mass loss at a temperature up to $110{ }^{\circ} \mathrm{C}$ due to the adsorbed water and total weight losses of about $12-18 \%$ up to $1000{ }^{\circ} \mathrm{C}$ in all of the samples, mainly due to the breakdown of serpentine minerals according to the literature data $[44,45]$. Some samples have high values of total water loss at $1000^{\circ} \mathrm{C}$ (i.e., $18 \%$ ) due to two reasons: (i) presence of other hydrated minerals in addition to the serpentine polymorphs (Table 1); and (ii) the presence of water (physically bound) trapped between the fibrous bundles of chrysotile [46]. 
Table 3. TG data (weight loss $\%$ up to $110^{\circ} \mathrm{C}$ and up to $1000^{\circ} \mathrm{C}$ ) for the analyzed samples.

\begin{tabular}{ccccc}
\hline & Spol1 & \multicolumn{3}{c}{ Spol2 } \\
\hline T range $\left({ }^{\circ} \mathrm{C}\right)$ & & TG loss $\%$ & T range $\left({ }^{\circ} \mathrm{C}\right)$ & TG loss $\%$ \\
\hline$<110$ & & 3.57 & $<110$ & 3.30 \\
TOT loss at 1000 & & 17.44 & TOT loss at 1000 & 14.80 \\
\hline & Spol3 & \multicolumn{2}{c}{ Spol5 } \\
\hline T range $\left({ }^{\circ} \mathrm{C}\right)$ & & TG loss $\%$ & T range $\left({ }^{\circ} \mathrm{C}\right)$ & TG loss $\%$ \\
\hline$<110$ & 1.47 & $<110$ & 3.94 \\
TOT loss at 1000 & & 13.13 & TOT loss at 1000 & 12.08 \\
\hline & Spol7 & \multicolumn{3}{c}{ Spol8 } \\
\hline T range $\left({ }^{\circ} \mathrm{C}\right)$ & & TG loss $\%$ & T range $\left({ }^{\circ} \mathrm{C}\right)$ & TG loss $\%$ \\
\hline$<110$ & & 2.16 & $<110$ & 2.39 \\
TOT loss at 1000 & & 12.24 & TOT loss at 1000 & 14.90 \\
\hline & Spol10 & \multicolumn{4}{c}{ Spol11 } & \\
\hline T range $\left({ }^{\circ} \mathrm{C}\right)$ & & TG loss $\%$ & T range $\left({ }^{\circ} \mathrm{C}\right)$ & TG loss $\%$ \\
\hline$<110$ & 1.96 & $<110$ & 2.78 \\
TOT loss at 1000 & 15.40 & TOT loss at 1000 & 15.42 \\
\hline
\end{tabular}

\section{Discussion and Conclusions}

The results obtained by thermal analysis and transmission electron microscope showed that chrysotile and asbestos tremolite are the asbestos minerals occurring in all of the analyzed soil samples in the area of san Severino Lucano village (southern Apennines). Chrysotile appears both as bundles and single fibrils with typical cylindrical shape with diameter and length shorter of 0.25 and $5 \mu \mathrm{m}$, respectively; it is interesting to point out as the most common morphology of chrysotile fibers is the classical cylindrical shape consisting of an empty central cavity throughout the length. Moreover, some chrysotile fibers are characterized by very thin outer walls and by wide central tube, proving that chrysotile, during the process of alteration in the passage from rock to soils underwent unrolling process from the inside; this is likely caused by the passage of water through the core. As far as occurring amphibole, results showed that it is tremolite, whose fibers exhibit prismatic rod-shaped morphology lacking of any flexibility. The average length ranges from $2.5 \mu \mathrm{m}$ to $3 \mu \mathrm{m}$ and the diameter is about $0.2 \mu \mathrm{m}$.

According to many authors, fibers shorter than $5 \mu \mathrm{m}$ and very thin $<0.25 \mu \mathrm{m}$ may have considerable carcinogenic potential [47-49]. Therefore, both techniques applied revealed to be a useful tool for determining the occurrence of asbestiform varieties and their morphological features in the studied soil samples, permitting asbestos minerals to be univocally identified and investigated in detailed, revealing that the fibers found within the studied soil samples show a size that may be associated with carcinogenesis when breathed.

It is important to specify that, in addition to the minerals regulated as asbestos by the Italian law, also asbestiform minerals such as fibrous antigorite could be potentially dangerous if inhaled [9]. In this work, polygonal serpentine and antigorite were the fibrous minerals detected in five and two samples respectively, while the other minerals identified were non-fibrous and most of them showing platy morphology (e.g., lizardite, chlorite). The village of San Severino is a significant example of a settlement built on NOA-bearing outcrops $[50,51]$ and the risk of inhaling airborne fibers of asbestos around the village increases due to the agricultural activities which are among the main resources for the economy of the area. The cultivation of soils developed on serpentinite bedrocks could provoke the fiber splitting into smaller fibrils that are widely spread out into the environment, increasing thus the exposure to them. Since asbestos occurrence in soils is a serious health problem, in many parts of the world, asbestos-containing land has been abandoned and countries with this problem have suffered economic losses due to depreciation of properties. The use of soils containing asbestos for agricultural purposes can increase the presence of fibers in the air, necessitating adequate attention to ensuring the protection of workers and general public, as already pointed out by dedicated agencies. It is useless to 
create unjustified alarmism in population; at the same time, inhabitants who live in countryside areas where NOA is present, should be aware that as now-a-days various techniques are available to limit or eliminate the presence of airborne fibers deriving from the processing of the soil, thus diminishing the risks related; among them, it is worth mentioning: (i) the use of tractors with air-conditioned and filtered cabins; (ii) wet the ground before hoeing it; (iii) wear overalls and masks suitable for protection from airborne asbestos fibers.

In conclusion, results presented in this work may provide a useful tool for planning prevention measures during human activities, in order to diminish negative effects of NOA on health.

Author Contributions: Conceptualization, A.B. and R.P.; Methodology (DSC-DTG and TEM-EDS measurements), A.B.; Software, A.B.; Validation, A.B., R.P. and C.R.; Formal Analysis, A.B.; Investigation, A.B., R.P. and C.R.; Resources, A.B. and R.P.; Data Curation, A.B. and R.P.; Writing-Original Draft Preparation, A.B., R.P. and C.R.; Writing-Review \& Editing, A.B., R.P. and C.R.; Visualization, A.B.; Supervision, R.P. and A.B.; Project Administration, R.P.; Funding Acquisition, R.P. and A.B.

Funding: Part of this research was carried out under the financial support of "Piano Triennale della Ricerca (2017-2020)" (Università di Catania, Dipartimento di Scienze Biologiche, Geologiche e Ambientali), scientific responsible Rosalda Punturo. The work has received financial support from the FFABR fund (by the Italian MIUR) scientific responsible Andrea Bloise.

Acknowledgments: The authors thank E. Barrese for the support during data collection. The work has received financial support from University of Calabria and University of Catania.

Conflicts of Interest: The authors declare no conflict of interest.

\section{References}

1. World Health Organization (WHO). Asbestos and Other Natural Mineral Fibers. Environmental Health Criteria, 53; World Health Organization: Geneva, Switzerland, 1986; p. 194.

2. National Institute for Occupational Safety and Health (NIOSH). Asbestos and Other Elongated Mineral Particles: State of the Science and Roadmap for Research; Current Intelligence Bulletin, June 2008-Revised Draft; National Institute for Occupational Safety and Health (NIOSH): Washington, DC, USA, 2008.

3. Punturo, R.; Cirrincione, R.; Pappalardo, G.; Mineo, S.; Fazio, E.; Bloise, A. Preliminary laboratory characterization of serpentinite rocks from Calabria (southern Italy) employed as stone material. J. Mediterr. Earth Sci. 2018, 10, 79-87.

4. International Agency for Research on Cancer (IARC). Asbestos (Chrysotile, Amosite, Crocidolite, Tremolite, Actinolite, and Anthophyllite) IARC Monographs. Arsenic, Metals, Fibers and Dusts; International Agency for Research on Cancer: Lyon, France, 2009; pp. 147-167.

5. Harper, M. 10th Anniversary critical review: naturally occurring asbestos. J. Environ. Monit. 2008, 10, 1394-1408. [CrossRef] [PubMed]

6. Compagnoni, R.; Ferraris, G.; Fiora, L. Balangeorite, a new fibrous silicate related to gageite from Balangero, Italy. Am. Mineral. 1983, 68, 214-219.

7. Ballirano, P.; Pacella, A.; Bloise, A.; Giordani, M.; Mattioli, M. Thermal Stability of Woolly Erionite-K and Considerations about the Heat-Induced Behaviour of the Erionite Group. Minerals 2018, 8, 28. [CrossRef]

8. Gianfagna, A.; Ballirano, P.; Bellatreccia, F.; Bruni, B.; Paoletti, E.; Oberti, R. Characterization of amphibole fibers linked to mesothelioma in the area of Biancavilla, eastern Sicily, Italy. Mineralog. Mag. 2003, 67, 1221-1229. [CrossRef]

9. Cardile, V.; Lombardo, L.; Belluso, E.; Panico, A.; Capella, S.; Balazy, M. Toxicity and Carcinogenicity Mechanisms of Fibrous Antigorite. Int. J. Environ. Res. Public Health 2007, 4, 1-9. [CrossRef] [PubMed]

10. Gualtieri, A.F. Mineral Fibers: Crystalchemistry, Chemical-Physicalproperties, Biological Interaction and Toxicity; European Mineralogical Union and Mineralogical Society of Great Britain and Ireland: London, UK, 2017; p. 533.

11. Pugnaloni, A.; Giantomassi, F.; Lucarini, G.; Capella, S.; Bloise, A.; Di Primio, R.; Belluso, E. Cytotoxicityinduced by exposure to natural and synthetic tremolite asbestos: An in vitro pilot study. Acta Histochem. 2013, 115, 100-112. [CrossRef] [PubMed]

12. Bloise, A.; Catalano, M.; Barrese, E.; Gualtieri, A.F.; Gandolfi, N.B.; Capella, S.; Belluso, E. TG/DSC study of the thermal behaviour of hazardous mineral fibers. J. Therm. Anal. Calorim. 2016, 123, 2225-2239. [CrossRef] 
13. Bloise, A.; Punturo, R.; Catalano, M.; Miriello, D.; Cirrincione, R. Naturally occurring asbestos (NOA) in rock and soil and relation with human activities: The monitoring example of selected sites in Calabria (southern Italy). Ital. J. Geosci. 2016, 135, 268-279. [CrossRef]

14. Censi, P.; Zuddas, P.; Randazzo, L.A.; Tamburo, E.; Speziale, S.; Cuttitta, A.; Punturo, R.; Santagata, R. Source and nature of inhaled atmospheric dust from trace element analyses of human bronchial fluids. Environ. Sci. Technol. 2011, 45, 6262-6267. [CrossRef] [PubMed]

15. Censi, P.; Tamburo, E.; Speziale, S.; Zuddas, P.; Randazzo, L.A.; Punturo, R.; Aricò, P. Yttrium and lanthanides in human lung fluids, probing the exposure to atmospheric fallout. J. Hazard. Mater. 2011, 186, 1103-1110. [CrossRef] [PubMed]

16. Bloise, A.; Barca, D.; Gualtieri, A.F.; Pollastri, S.; Belluso, E. Trace elements in hazardous mineral fibres. Environ. Pollut. 2016, 216, 314-323. [CrossRef] [PubMed]

17. Punturo, R.; Bloise, A.; Critelli, T.; Catalano, M.; Fazio, E.; Apollaro, C. Environmental implications related to natural asbestos occurrences in the ophiolites of the Gimigliano-Mount Reventino Unit (Calabria, southern Italy). Int. J. Environ. Res. 2015, 9, 405-418.

18. Acosta, A.; Pereira, M.D.; Shaw, D.M.; Bea, F. Serpentinización de la peridotita de Ronda (cordillera Betica) comorespuesta a la interacción con fluidosricos en volátiles: comportamiento del boro. Rev. Soc. Geol. Esp. 1997, 10, 99-106.

19. Burragato, F.; Comba, P.; Baiocchi, V.; Palladino, D.M.; Simei, S.; Gianfagna, A.; Pasetto, R. Geo-volcanological, mineralogical and environmental aspects of quarry materials related to pleural neoplasm in the area of Biancavilla, Mount Etna (Eastern Sicily, Italy). Environ. Geol. 2005, 47, 855-868. [CrossRef]

20. Constantopoulos, S.H. Environmental mesothelioma associated with tremolite asbestos: Lessons from the experiences of Turkey, Greece, Corsica, New Caledonia and Cyprus. Regul. Toxicol. Pharmacol. 2008, 52, 110-115. [CrossRef] [PubMed]

21. Pereira, M.D.; Peinado, M.; Blanco, J.A.; Yenes, M. Geochemical characterization of serpentinites at cabo ortegal, northwestern Spain. Can. Mineral. 2008, 46, 317-327. [CrossRef]

22. Bloise, A.; Belluso, E.; Critelli, T.; Catalano, M.; Apollaro, C.; Miriello, D.; Barrese, E. Amphibole asbestos and other fibrous minerals in the meta-basalt of the Gimigliano-Mount Reventino Unit (Calabria, south-Italy). Rend Online Soc Geol It. 2012, 21, 847-848.

23. Navarro, R.; Pereira, D.; Gimeno, A.; Barrio, S.D. Verde Macael: A Serpentinite Wrongly Referred to as a Marble. Geosciences 2013, 3, 102-113. [CrossRef]

24. Gaggero, L.; Sanguineti, E.; Yus González, A.; Militello, G.M.; Scuderi, A.; Parisi, G. Airborne asbestos fibers monitoring in tunnel excavation. J. Environ. Manag. 2017, 196, 583-593. [CrossRef] [PubMed]

25. Worliczek, E. Naturally occurring asbestos: The perception of rocks in the mountains of New Caledonia. In Environmental Transformations and Cultural Responses: Ontologies, Discourses, and Practices in Oceania; Dürr, E., Pascht, A., Eds.; Springer: Berlin, Germany, 2017; pp. 187-214.

26. Bloise, A.; Catalano, M.; Critelli, T.; Apollaro, C.; Miriello, D. Naturally occurring asbestos: Potential for human exposure, San Severino Lucano (Basilicata, Southern Italy). Environ. Earth Sci. 2017, 76, 648. [CrossRef]

27. Bernardini, P.; Schettino, B.; Sperduto, B.; Giannadrea, F.; Burragato, F.; Castellino, N. Tre Casi di mesotelioma pleurico ed inquinamento ambientale da rocce affioranti di tremolite in Lucania. GIMLE 2003, 25, 408-411.

28. Burragato, F.; Mastacchi, R.; Papacchini, L.; Rossini, F.; Sperduto, B. Mapping of risks due to particulates of natural origin containing fibrous tremolite: The case of Seluci di Lauria (Basilicata, Italy). In Proceedings of the 1st General Assembly, Nice, France, 25-30 April 2004.

29. Pasetto, R.; Bruni, B.; Bruno, C.; Cauzillo, G.; Cavone, D.; Convertini, L.; De Mei, B.; Marconi, A.; Montagano, G.; Musti, M.; et al. Mesotelioma pleurico ed esposizione ambientale a fibre minerali: Il caso di un'area rurale in Basilicata. Ann. Ist. Super. Sanita. 2004, 40, 251-265. [PubMed]

30. Punturo, R.; Ricchiuti, C.; Mengel, K.; Apollaro, C.; De Rosa, R.; Bloise, A. Serpentinite-derived soils in southern Italy: Potential for hazardous exposure. J. Mediterr. Earth Sci. 2018, 10, 51-61.

31. Monaco, C.; Tortorici, L. Tettonica estensionale quaternaria nell'Arco Calabro e in Sicilia orientale. Studi Geologici Camerti 1995, 2, 351-362.

32. Monaco, C.; Tortorici, L.; Paltrinieri, W. Structural evolution of the Lucanian Apennines, southern Italy. J. Struct. Geol. 1998, 20, 617-638. [CrossRef] 
33. Vezzani, L. La Formazione del Frido (Neocomiano- Aptiano) tra il Pollino e il Sinni. Geol. Rom. 1969, 8 , 129-176.

34. Amodio Morelli, L.; Bonardi, G.; Colonna, V.; Dietrich, D.; Giunta, G.; Ippolito, F.; Liguori, V.; Lorenzoni, S.; Paglioncino, A.; Perrone, V. L' arco Calabro Peloritano nell' orogene Appenninico-Maghrebide. Mem. Soc. Geol. It. 1976, 17, 1-60.

35. Vezzani, L. La sezione tortoniana di Perosa sul fiume Sinni presso Episcopia (Potenza). Geol. Rom. 1966, 5, 263-290.

36. Sansone, M.T.C.; Rizzo, G.; Mongelli, G. Petrochemical characterization of mafic rocks from the Ligurian ophiolites, Southern Apennines. Int. Geol. Rev. 2011, 53, 130-156. [CrossRef]

37. Rizzo, G.; Cristi Sansone, M.T.; Perri, F.; Laurita, S. Mineralogy and petrology of the metasedimentary rocks from the frido unit (southern apennines, Italy). Period. Mineral. 2016, 85, 153-168.

38. Sansone, M.T.C.; Prosser, G.; Rizzo, G.; Tartarotti, P. Spinel-peridotites of the frido unit ophiolites (southern apennine-italy): Evidence for oceanic evolution. Period. Mineral. 2012, 81, 35-59.

39. Whitney, D.L.; Evans, B.W. Abbreviations for names of rock-forming minerals. Am. Mineral. 2010, 95, 185-187. [CrossRef]

40. Leake, B.E.; Woolley, A.R.; Arps, C.E.S.; Birch, W.D.; Gilbert, M.C.; Grice, J.D.; Hawthorne, F.C.; Kato, A.; Kisch, H.J.; Krivovichev, V.G.; et al. Nomenclature of amphiboles: Report of the subcommittee on amphiboles of the international mineralogical association, commission on new minerals and mineral names. Can. Mineral. 1997, 35, 219-246.

41. Bloise, A.; Barrese, E.; Apollaro, C.; Miriello, D. Flux growth and characterization of Ti and Ni doped forsterite single crystals. Cryst. Res. Technol. 2009, 44, 463-468. [CrossRef]

42. Bloise, A.; Catalano, M.; Gualtieri, A.F. Effect of Grinding on Chrysotile, Amosite and Crocidolite and Implications for Thermal Treatment. Minerals 2018, 8, 135. [CrossRef]

43. Bloise, A.; Kusiorowski, R.; Gualtieri, A.F. The Effect of Grinding on Tremolite Asbestos and Anthophyllite Asbestos. Minerals 2018, 8, 274. [CrossRef]

44. Ballirano, P.; Bloise, A.; Gualtieri, A.F.; Lezzerini, M.; Pacella, A.; Perchiazzi, N.; Dogan, M.; Dogan, A.U. The Crystal Structure of Mineral Fibers. In Mineral Fibers: Crystal Chemistry, Chemical-Physical Properties, Biological Interaction and Toxicity; Gualtieri, A.F., Ed.; European Mineralogical Union: London, UK, 2017; Volume 18, pp. 17-53.

45. Bloise, A.; Kusiorowski, R.; Lassinantti Gualtieri, M.; Gualtieri, A.F. Thermal behaviour of mineral fibers. In Mineral Fibers: Crystal Chemistry, Chemical-Physical Properties, Biological Interaction and Toxicity; Gualtier, A.F., Ed.; European Mineralogical Union: London, UK, 2017; Volume 18, pp. 215-252.

46. Loomis, D.; Dement, J.; Richardson, D.; Wolf, S. Asbestos fibre dimensions and lung cancer mortality among workers exposed to chrysotile. Occup. Environ. Med. 2010, 67, 580-584. [CrossRef] [PubMed]

47. Suzuki, Y.; Yuen, S.R.; Ashley, R. Short, thin asbestos fibersc ontribute to the development of human malignant mesothelioma: Pathological evidence. Int. J. Hyg. Environ. Health 2005, 208, 201-210. [CrossRef] [PubMed]

48. Bernstein, D.; Castranova, V.; Donaldson, K.; Fubini, B.; Hadley, J.; Hesterberg, T.; Kane, A.; Lai, D.; McConnell, E.E.; Muhle, H.; et al. Testing of fibrous particles: Short-term assays and strategies. Inhal. Toxicol. 2005, 17, 497-537. [CrossRef] [PubMed]

49. Stanton, M.F.; Layard, M.; Tegeris, A.; Miller, E.; May, M.; Morgan, E.; Smith, A. Relation of particle dimension to carcinogenicity in amphibole asbestoses and other fibrous mineral. J. Natl. Cancer. Inst. 1981, 67, 965-975. [PubMed]

50. Dichicco, M.C.; Laurita, S.; Sinisi, R.; Battiloro, R.; Rizzo, G. Environmental and Health: The Importance of Tremolite Occurence in the Pollino Geopark (Southern Italy). Geosciences 2018, 8, 98. [CrossRef]

51. Bellomo, D.; Gargano, C.; Guercio, A.; Punturo, R.; Rimoldi, B. Workers' risks in asbestos contaminated natural sites. J. Mediterr. Earth Sci. 2018, 10, 97-106.

(C) 2019 by the authors. Licensee MDPI, Basel, Switzerland. This article is an open access article distributed under the terms and conditions of the Creative Commons Attribution (CC BY) license (http:/ / creativecommons.org/licenses/by/4.0/). 